\title{
Does India Really Need to Export Fish: Reflections and Upshots
}

\author{
Shyam S. Salim ${ }^{1}$, P.K. Safeena and N.R. Athira \\ Socio-Economic Evaluation and Technology Transfer Division \\ Central Marine Fisheries Research Institute, Cochin-682018, Kerala
}

\begin{abstract}
The paper has studied the status of fish food security in India — production across sectors, export growth - analysing price realization in the domestic and export markets. The study has derived macro-economic estimates using primary and secondary data on fish production, consumption, distribution and exports on a spatio-temporal platform. The study has revealed that contrary to the classic demand theory, the willingness to pay a higher price does exist among the urban consumers. The decomposition analysis has indicated that export value realization is primarily due to "quantity effect" not by "price effect". The price comparison of exported fish species has indicated higher prices in domestic than export market. The study has revealed significant deleterious fish demand-supply mismatch in domestic market and has advocated for government interventions in regulating fish exports. The paper has suggested adoption of concerted efforts for augmenting domestic fish consumption of high-value fishes through conducting awareness programmes for the masses.
\end{abstract}

Key words: Fish food security, fish export paradox, decomposition analysis, willingness to pay, domestic valuation, fish export

JEL Classification: Q22, Q48, Q41, N55, F31

\section{Introduction}

Fishing as an occupation is being practiced in India since time immemorial and is the primary enterprise of the fishermen community for their subsistence with little external input. Over the years, the sector has emerged and plays a strategic role in food security, international trade and employment generation. Indian economy has grown consistently post-liberalization with higher purchasing power and consistent demand for diversified food products. The consumption behaviour has skewed towards protein-rich food with increasing fish consumption on account of being healthier and cheaper food amongst animal protein substitutes. With changing consumption pattern, emerging market forces and technological

\footnotetext{
* Author for correspondence

Email: shyam.icar@gmail.com
}

developments, the fisheries sector has assumed added importance in India and is undergoing a rapid transformation. The present fish production is 10.15 Mt with a contribution of $3.58 \mathrm{Mt}$ from marine sector and $6.57 \mathrm{Mt}$ from inland sector. The contribution of fisheries to GDP is ₹ 78,053 crores which is around 0.83 per cent of the total GDP. The sector contributes about 4.75 per cent to the agriculture GDP. The vibrancy of the sector could be identified from the fact that it has registered an eleven-fold increase in production over the past five decades.

The export sector has grown at around 10 per cent over the years and the export earnings were ₹ 33411 crores in 2014-15. India's seafood export has surged new heights and continued unabated amidst global recession (Salim and Narayanakumar, 2012). The exports target more than 120 countries with considerable commodities diversification. The 
increasing export demand has resulted in the movement of fish from domestic markets to export markets. Some of the varieties of fish so far catering to the poor and upend domestic markets - most importantly seer fishes, ribbon fishes, snappers, groupers, cephalopods, pomfrets - have now begun to be exported in large quantities. This results in a lower supply of these fishes to the domestic markets and increases competition and prices for consumers. This has also caused changes in targeting of trawling and artisanal operations in favour of these species and has contributed to the sudden increases in price of these products (DFID, 2003).

\section{Demand and Supply of Fish in India by 2030}

The demand and supply of fish in the years 2017 , 2020, 2025 and 2030 were calculated assuming the population of India to be 1.28 billion, 1.36 billion, 1.45 billion and 1.53 billion, respectively with 60 per cent population consuming fish @ $12 \mathrm{~kg} /$ capita and are presented in Table 1. A perusal of Table1 shows that the supply demand gap would be of $1.75 \mathrm{Mt}$ by 2017 and would double by 2030 (Salim, 2013).

Fish also poses considerable domestic food security challenges for the future on account of its unregulated multiple uses, including exports, industrial uses, offal for reductions and wastages, and discards, live fish feeds for capture based aquaculture, fish meal industry and as baits. The fish prices in domestic market are rising leading to issues of fish availability, accessibility and affordability (Salim et al., 2015). Under this scenario, the study has analysed the trends in fish landings, export growth and domestic trade and has identified the factors affecting the domestic fish consumption along with the constraints in export of fish. It has also compared the fish price behaviour across export and domestic markets.

\section{Data and Methodology}

The study is based on both primary and secondary data. The secondary data included marine fish landings and inland landings sourced from different published sources including FAO Year Book of Fishery Statistics, Statistics of Marine Product Export from India, published by the Marine Products Export Development Authority (MPEDA, Cochin), Ministry of Commerce, Government of India, and National Marine Living Resource Data Centre, Central Marine Fisheries Research Institute. The primary data on fish consumption were collected from 900 consumer households from urban and semi-urban locales in Kerala, Tamil Nadu and Maharashtra. The primary data on the pattern of expenditure, fish consumption, buying behaviour, constraints in high-value fish consumption, willingness to pay for high value fishes, etc. were collected using a structured survey schedule. The exporters profiling was done for 60 processors by using a pre-tested interview schedule to identify the constraints faced by seafood exporters across selected states of Kerala, Tamil Nadu and Maharashtra.

To find trends in landings and export of fish, growth rate analysis was carried out. The problems in fish consumption as well as export were ranked by Garrette Ranking technique (Garette, 1969). Logit model was used to find the consumers' willingness to pay (WTP) for high-value fishes (Lusk and Hudson, 2004; Maynard and Franklin, 2003). To find source of growth and variability in domestic trade and export performance, Hazell Decomposition model was used (Hazell, 1982; Hazell et al., 1987).

Table 1. Fish demand and supply gap in India by 2030

( in $\mathrm{Mt}$ )

\begin{tabular}{|c|c|c|c|c|c|c|c|c|}
\hline \multirow[t]{2}{*}{ Year } & \multicolumn{3}{|c|}{ Fish demand } & \multicolumn{4}{|c|}{ Fish supply } & \multirow{2}{*}{$\begin{array}{c}\text { Demand- } \\
\text { supply } \\
\text { gap }\end{array}$} \\
\hline & Domestic & $\begin{array}{c}\text { Exports / } \\
\text { Industrial/ } \\
\text { Processing }\end{array}$ & Total & Marine & Inland & Imports & Total & \\
\hline 2017 & 9.22 & 2.48 & 11.7 & 4.10 & 5.72 & 0.1 & 9.92 & 1.78 \\
\hline 2020 & 10.61 & 2.64 & 13.25 & 4.30 & 6.07 & 0.21 & 10.58 & 2.67 \\
\hline 2025 & 12.18 & 2.82 & 15.00 & 4.51 & 6.43 & 0.33 & 11.27 & 3.73 \\
\hline 2030 & 12.85 & 3.03 & 15.88 & 4.74 & 6.82 & 0.58 & 12.14 & 3.74 \\
\hline
\end{tabular}




\section{Results and Discussion}

\section{Sectoral Performance}

The performance of fisheries sector in terms of production/ landings over the years is presented in Figure 1. It can be seen that contribution of marine sector reduced from 58.86 per cent in 1991 to 35.94 per cent in 2014, whereas contribution of inland sector increased from 41.14 per cent in 1991 to 64.70 per cent in 2014 (FAO, 2005; CMFRI, 2014; 2015).

The marine fish landings, which are around $4 \mathrm{Mt}$ in the country, are almost reaching a plateau. The marine fisheries sector is grappled with numerous constraints like over-exploitation, targeted fishing, juvenile fish capturing, property rights regime, degradation of habitats and open access to the fishery. Climate change has also exacerbated the status of fisheries with reduced landings and range shifts of fish species ( Vivekanandan, 2011; Sathianandan et al., 2011; Mohamed et al., 2014).

The inland sector continues to show signs of improvement but is deterred by constraints such as less area developed under aqua farming, provision of low level of supplementary feed, non-availability of fingerlings of desired size and species, lack of diversification of aquaculture practices, lack of standardized technology, non-development of location-specific culture technology, low production levels of different aquaculture systems and nonavailability of credit facilities and aquaculture insurance schemes.

\section{Export performance}

During 1985-2014, the export of marine products has been found increasing and was directly related to marine fish landings. The share of export has steeply increased from 2001 onwards and even with marginal growth in landings over the years, the exports have grown considerably. The relationships between the landings, export and catch per unit effort (CPUE) were estimated and are depicted graphically in Figures 2 and 3, respectively (Salim et al., 2010). A positive relationship has been observed between the quantity exported and total CPUE of the vessels. Whenever landing increased, the CPUE also increased directly (Figure 3).

The export of marine products from India reached one million tonne mark, with worth of US\$ 5.51 billion in 2014-15 and registered an impressive double digit growth rate since $2007-08$ post- recessions. India exports frozen shrimp, squids and finfish in dried, live and chilled forms to different destinations. The sector is poised for a robust growth with anticipated earnings of US\$ 6.6 billion in 2016-17. This does assumes significance during the period of continued recession among the major buyers (Figure 4).

The major trading partners, including the US, EU and Japan are under the effect of severe recessionrelated economic indicators like lack of investment, lower purchasing power, acute unemployment, etc. However, on the brighter side, there exists a huge domestic demand as is evident from the high domestic

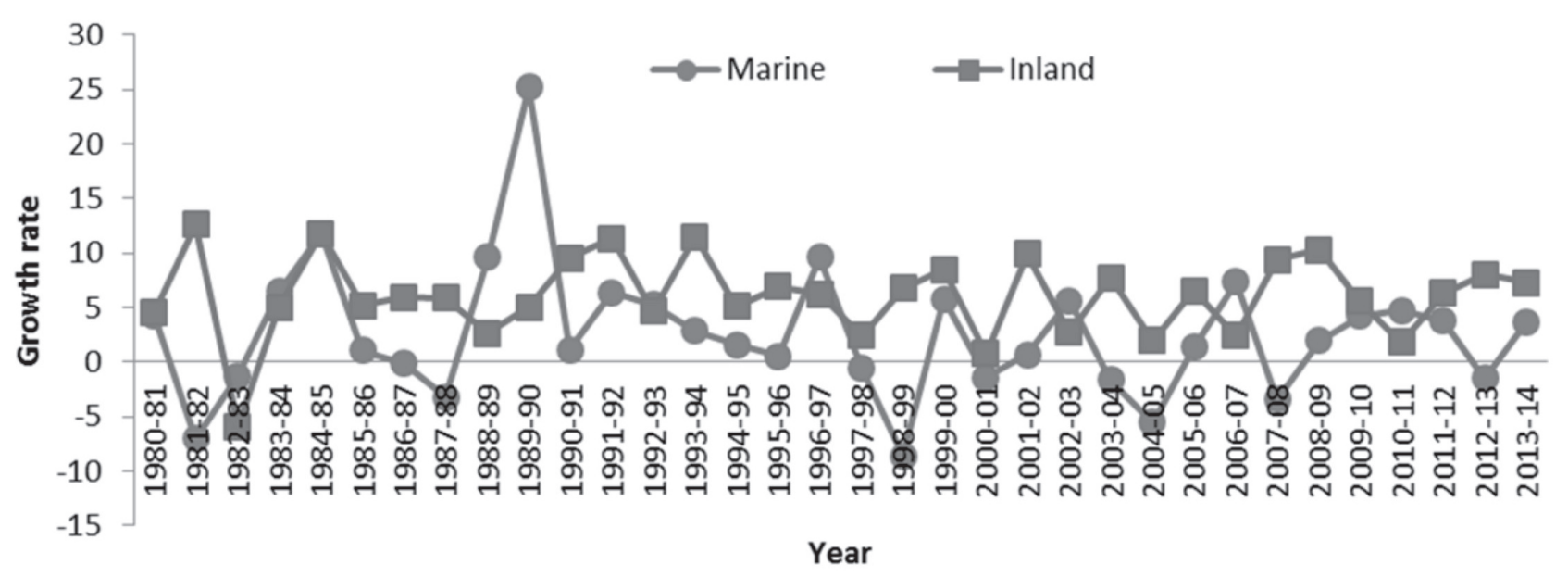

Figure 1. Performance of fisheries sector based on production/ landings, 1980-81 to 2013-14 


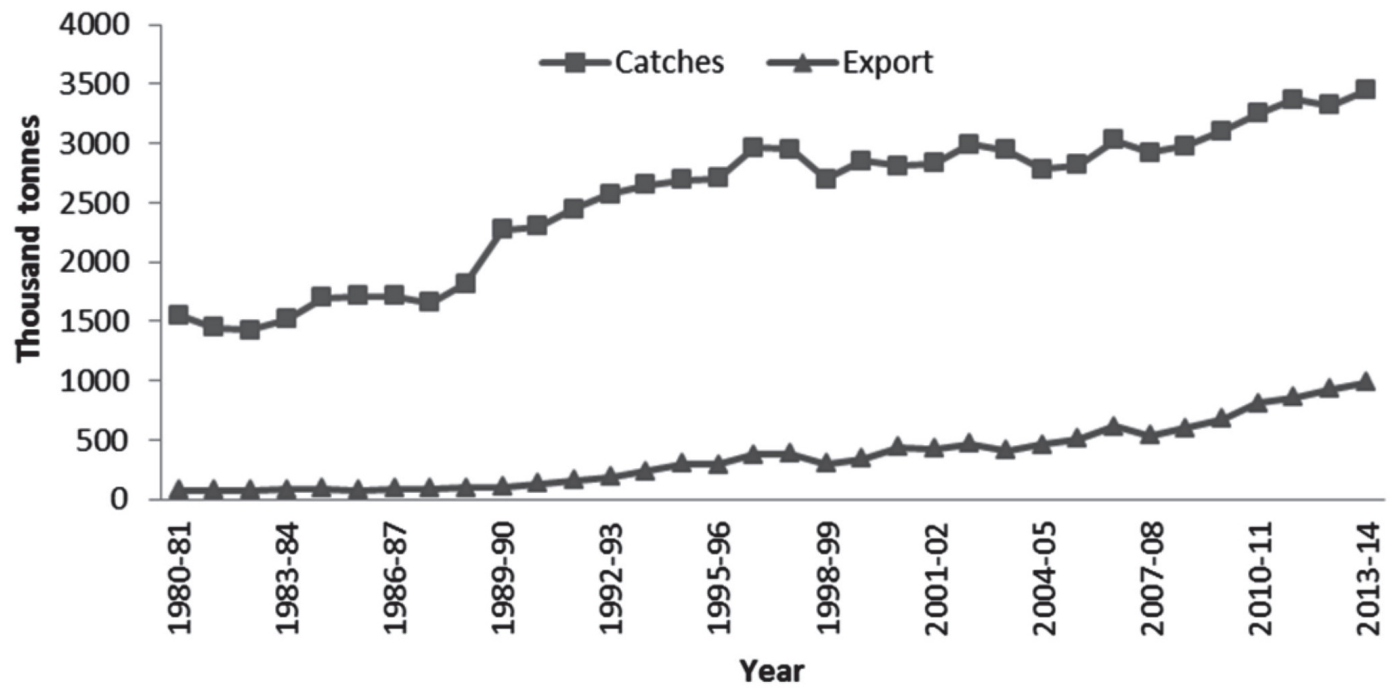

Figure 2. All India landings and export of fish, 1980-2013

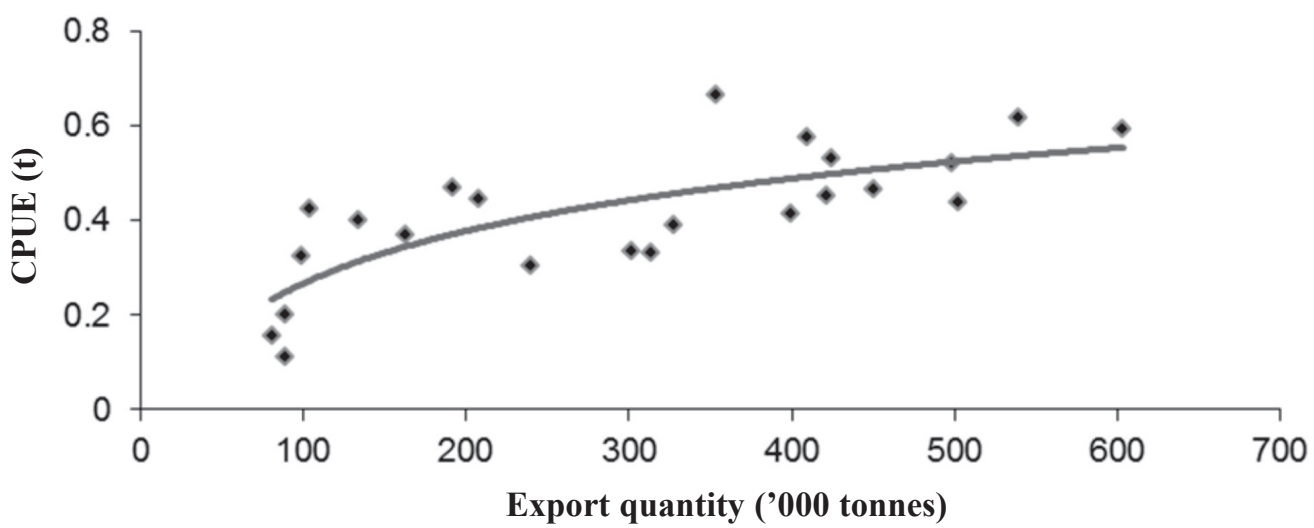

Figure 3. Fish exports vs Catch per unit effort (CPUE)

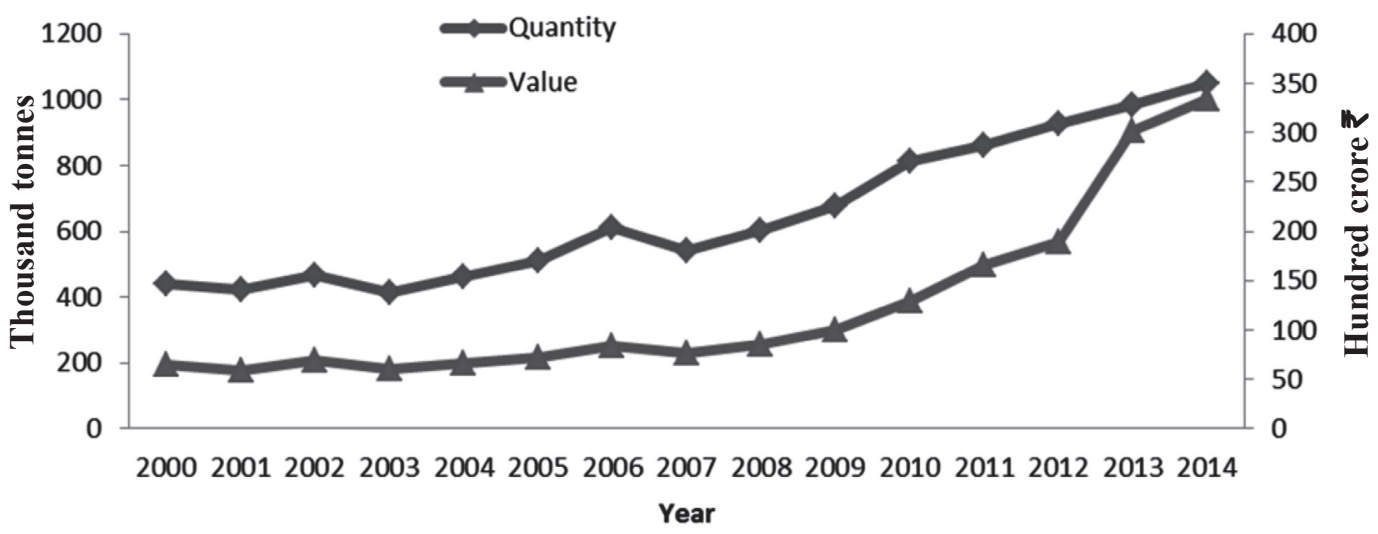

Figure 4. Export quantum of fish from India, 2000-2014

prices and consumers' preferences towards fish and fish-related products. Amidst impressive performance, the fish export is facing constraints like timely availability of raw material, low capacity utilization, high cost of production, high prices of raw materials, high cost on compliance for meeting the quality standards of buyer countries, incidence of alert and rejections and continued trade impediments (Salim et al.,2004; Joseph and Salim, 2012; Sathiadhas and Femeena, 2002). 


\section{Constraints in Export of Fish}

There is severe paucity of raw materials due to depleted landings in the marine sector and disease incidence in the culture sector. The major exportable species such as shrimps, lobsters and high-value fishes have registered a downward trend in landings over the years. There has also been a significant reduction in shrimp production due to disease outbreak and huge cost of shrimp farming. The reduction in landings coupled with geographical separation of landings often result in irregular supply of raw materials, resulting in non-realization of economies of scale for exporters. In addition, the seasonal variations in marine catches constrain the operations of the firms.

During lean seasons, the majority of firms face shortage of raw materials resulting in low capacity utilization (Unnithan et al., 1998). The bigger firms having access to backward integration or owning fishing vessels may operate to some extent, but the smaller firms either lay idle or limit their operations. The peak landings in the marine capture sector generally coincide with the peak season for exports. More than 60 per cent of the landings occur during the post-monsoon period which coincides with the highest export demand period. Thus, to restore parity between demand and supply, raw materials are often purchased at higher prices with even forward marketing with the boat owners.

The increasing demand for fish in the domestic market may push up the prices of many exportable fish varieties. The high purchase price and other operating expenses like labour cost, water and electricity charges increase the cost of production to exorbitant levels. In addition, the high cost on compliance for EU approval, high cost incurred for purchase at distant markets and establishment cost all result in higher unit cost of production and lower profit margins. The overall compliance cost for meeting the EU norms has been estimated to be $15-40$ per cent of the FOB value. Often the cost of investment is so huge that the break evens aren't even attained after a decade of continuance in business.

There exists uncertainty in prices in the international market with the economic recession spreading to most of the target markets. The price uncertainties lead to delay in payments, loss in revenue, delay in realising new markets, additional cost on storage, delay in shipment and increased demurrages. In addition, ecolabelling and other private standards by international retailers for environmental and social purposes also result in high costs and low margins in fish export.

\section{Consumption Profile}

According to Evolution Sports Nutrition (ESN) the country profile for India (FAO, 2005) has reported that fish and seafood provide 2 per cent of the dietary energy supply while cereals supply 62 per cent. The per capita annual consumption of fish is estimated to be $5 \mathrm{~kg}$ for whole population and $8 \mathrm{~kg}$ for non-vegetarian population as against the world average of $16 \mathrm{~kg}$. The study puts the rate of growth of fish consumption in India and the South East Asia as having doubled over the period 1973-1997(Krishnan and Birthal, 2002; Delgado et al., 2003). It is estimated that the Indian population may cross 1.4 billion mark by 2020 and the estimated demand for fish will be $9.5 \mathrm{Mt}$. It means that from the present level of fish production of 5.9 $\mathrm{Mt}$, the production will have to be nearly doubled by 2020 (FAO, 2006).

At all-India level, fish constitutes about 58 per cent of the total non-vegetarian food. Wide regional variations exist in fish consumption; it is higher in southern, eastern and north-eastern states and lower in western and northern states, the lowest being in the western states. The fish consumption has depicted an increasing trend; during the period 1983-2000, it increased from $6.97 \mathrm{~kg} /$ year/ capita to $9.12 \mathrm{~kg} /$ capita in the rural areas and from $8.01 \mathrm{~kg} / \mathrm{year} /$ capita to 11.05 $\mathrm{kg} /$ capita in the urban areas. The level of fish consumption is influenced by income and its easy availability. The growth in fish consumption has been found higher in non-poor and rich households and stagnating across poor households. The fish prices became higher on moving from very poor to non-poor, rural to urban and coastal to non-coastal states. This reflects that apart from other factors, quality consideration in purchase of fish is also high for rich households.

The consumption of fish in India is increasing significantly due to lifestyle changes and higher cost of meat. In addition, the perception of fish as a healthy food with high levels of digestible protein, PUFA and lowering cholesterol capability is also a major factor for its increased consumption. The phenomenon is 
gradually spreading beyond hypermarkets and supermarkets (Ghosal, 2011).

The consumption studies were conducted across 900 urban households in Chennai, Kochi and Mumbai. The study found that domestic prices were 20-25 per cent more than export price; nevertheless, a sizeable demand did exist with high consumer surplus (Salim, 2012). The average fish consumption / household has been found to be around $10 \mathrm{~kg}$. The fishes consumed included both low value (sardines, mackerels, anchovies and others) and high- value (shrimps, cephalopods, seer fishes, pomfrets, ribbon fishes and others ) fishes and were consumed 70 per cent and 30 per cent, respectively.

The constraint analysis has indicated that reduced availability, seasonal consumption and exorbitant prices were the major constraints. Most domestic consumers were unaware about low export price. The study has revealed significant deleterious effects of fish supply-demand mismatch in domestic market and advocates for government intervention to ensure fish food security.

\section{Willingness to Pay}

The contingent valuation method was employed to measure the consumer's willingness to pay for highvalue fishes. A total of 49.9 per cent of the respondents were ready to pay more if fishes were available. It was found that 70.79 per cent of the consumers felt that they rarely get high-value fishes for consumption. About 35.25 per cent of the respondents preferred to eat high-value fishes frequently if available. The majority of respondents (70.79 per cent) opined that they rarely / never get high-value fishes.

The results indicated that the willingness to pay for fish had positive association with age, education, income, price of substitutes and taste and preferences. The willingness to pay was adversely affected by proximity to the buying source. It was surprising to find that the consumers were willing to pay for highvalue fishes was more with increasing price of fish, indicating high consumer surplus. It was found that for every 10 per cent increase in the price of fish, the willingness to pay increased by 0.8 per cent from the mean level ceteris paribus. The willingness to pay function also ascertained the growing demand for fish consumption even at higher prices.

\section{Paradox of Export}

The domestic fish food security is an important issue considering the fact that export prices of fish are lower than the domestic prices, coupled with umpteen trade restrictions and measures. It is important to ensure the availability and affordability of high-value fishes whose consumption could be augmented by creating awareness in the country. The awareness level on highvalue fish consumption has indicated that only 15.3 per cent of the consumers were aware about export prices of high-value fishes being low compared to its domestic prices.

The study has observed that exports of fish have been done at a price lower than domestic retail price (less than a dollar) across 42 countries. The price comparison of the high-value species like cephalopods, pomfrets, seer and ribbon fishes has indicated that the domestic prices were on an average 20-25 per cent more than the export prices (Salim et al., 2012). It is mainly because of the fact that the high-value fishes do not cater to the domestic market on account of low and inconsistent demand. The exporters in order to reap in the export economies of scale tend to export more quantity at a lower price margin. The revenue gains are contributed mostly by quantity effect rather than the price effect. The exporters make their revenue mostly out of selling more quantities rather than at competitive prices (Salim and Geetha, 2011). The paradox of selling a higher quantity at a lower export price coupled with buyer alerts and rejections necessitates the need for harnessing the domestic market so that the fish food is available across the Indian masses.

\section{Domestic Valuation}

In 2014, the value of marine fish landings in India was estimated to be at $₹ 31,750$ crores at landing centre (LC) level and ₹ 52,360 crores at the retail centre (RC) level (CMFRI, 2015). The value at the landing centre level registered an increase of 8.10 per cent, while that at the retail centre level, it increased at the rate of 12.10 per cent over the previous year 2013. The domestic fish market is growing significantly with population and income growth rates, changes in food habits, increasing awareness on nutritional qualities of fish, improvements in transportation, storage and processing facilities and access to quality fish (Figure 5). The 
Salim et al. : Does India Really Need to Export Fish: Reflections and Upshots

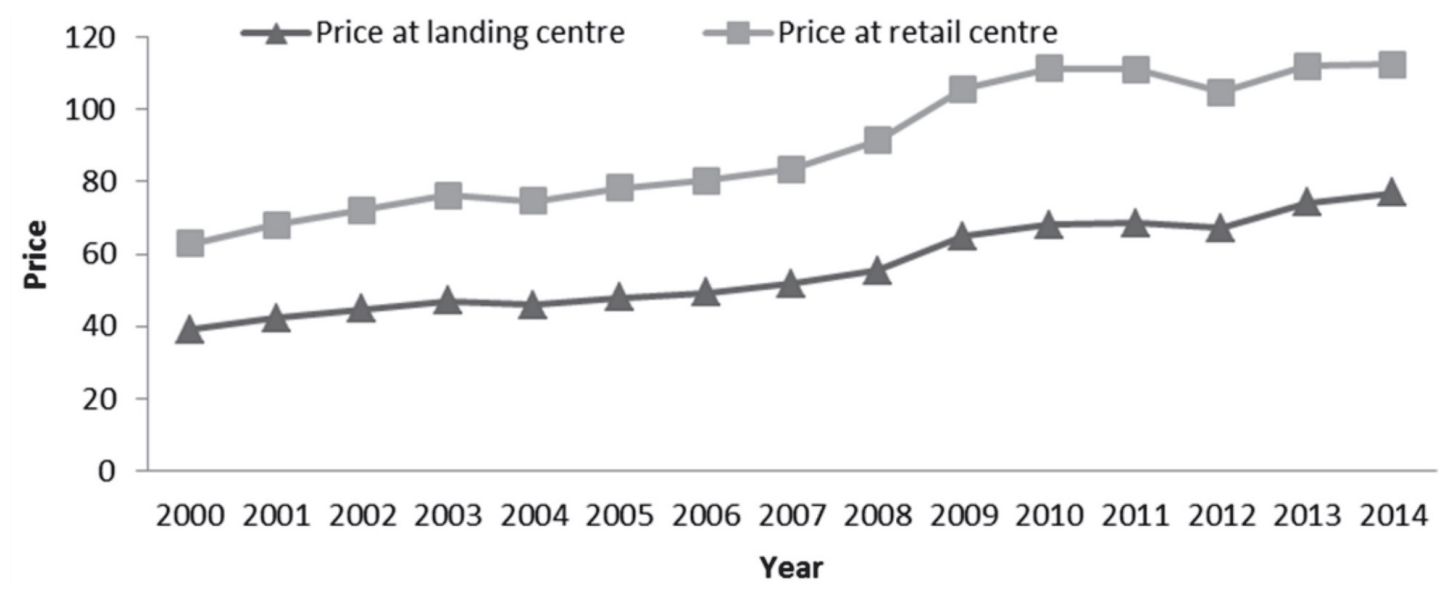

Figure 5. Growth in domestic marine fish prices at first and last sales (2000-2014) (₹/ kg)

average price at landing centre was found to be $₹ 76.98$ and at retail centre it was ₹ 112.35

\section{Domestic Marketing vis-a-vis Export Trade}

A comparison of domestic marketing and export trade was attempted using the decomposition model for two time periods - Export trade (pre- and postWTO) and Domestic marketing (Period I : 2000-2008 and Period II : 2009-2014). The domestic retail price and export price of exported species was compared across three time periods, viz., 1997-1998, 2007-08 and 2014-15. To find the source of growth and variability in Indian export /domestic trade in fishes, the Hazell's decomposition model was employed. The decomposition model identifies the source of change in the average export value under change in mean value, changes in mean quantity, its interactions and its covariances. The results, given in Table 2, reveal that contribution of change in mean export quantity was the highest 59.66 among the other components of change. This was as per expectation because the export quantity had recorded significant higher growth rates during both the periods, whereas the export unit value had recorded a negative growth rate during the postWTO period. The changes in covariance could arise through the changes in the variance of export quantity and export unit value. With regard to interaction effect, the export quantity was benefited to an extent of 26.43 per cent from both mean export quantity and mean export unit value. The study has indicated clearly that the export earning value is mostly due to "quantity effect" rather than the "price effect".

In the case of the domestic marketing it was found that the changes in mean value registered a 43.31 per cent in comparison with the changes in mean quantity $(40.69 \%)$. The interaction effect was found to be 15.56 per cent. However in the case of the domestic valuation the "price effect is more than the quantity effect.

\section{A Comparison of Export Price vis-a-vis Domestic Price}

Table 3 enlists the prices of exportable fish species across export and domestic markets realized for the years 1997-98, 2007-08 and 2014-15. It shows that the rise in prices of these fish species was much higher in domestic markets than in the export market. Apart from shrimps and cuttle fish, most of the fishes could fetch a higher domestic price when compared to its export price.

Table 2. Components of change in average value of fish

\begin{tabular}{lcc}
\hline Source of change & Export (\%) & Domestic market (\%) \\
\hline Change in mean value & 12.81 & 43.31 \\
Change in mean quantity & 59.66 & 40.69 \\
Interaction between changes in mean value and quantity & 26.43 & 15.56 \\
Change in quantity and value - EUV covariance & 1.07 & 0.44 \\
\hline
\end{tabular}


(Conference Number) 2015

Table 3. Export price vis- a-vis domestic price realization - A comparison of exportable fish species

\begin{tabular}{lccccccc}
\hline Species & \multicolumn{3}{c}{ Export market } & & \multicolumn{3}{c}{ Domestic market } \\
\cline { 2 - 3 } \cline { 7 - 8 } & $1997-1998$ & $2007-08$ & $2014-15$ & & $1997-1998$ & $2007-08$ & $2014-15$ \\
\hline Ribbon fish & 27 & $52(93)$ & $87(67)$ & & 16 & $50(213)$ & $145(190)$ \\
Pomfret & 172 & $228(33)$ & $358(57)$ & & 120 & $248(107)$ & $425(71)$ \\
Tuna & 38 & $58(53)$ & $84(45)$ & & 25 & $49(96)$ & $187(282)$ \\
Mackerel & 40 & $64(60)$ & $107(67)$ & & 30 & $59(97)$ & $171(190)$ \\
Sardine & 34 & $21(-38)$ & $40(90)$ & & 25 & $42(68)$ & $72(71)$ \\
Seerfish & 67 & $133(99)$ & $396(197)$ & & 73 & $265(263)$ & $436(65)$ \\
Squids & 75 & $118(57)$ & $198(68)$ & & 78 & $117(50)$ & $217(85)$ \\
Cuttle fish & 84 & $160(90)$ & $202(26)$ & & 78 & $117(50)$ & $200(71)$ \\
Shrimps & 292 & $297(2)$ & $542(82)$ & & 195 & $242(24)$ & $391(62)$ \\
\hline
\end{tabular}

Note: *Figures within the parentheses indicate percentage change over the previous period

\section{Conclusions}

Among non-traditional exports, fish and fishery products play a prominent role contributing significantly to the success of India's export effort. They have become one of the major foreign exchange earners in the agricultural and allied sector of India in recent years. The sustained increase in export is due to the demand for raw fish rather than the value-added products from the retail outlets. The study has pointed out that amidst the global recession and economic meltdown, the sector performed well. Contrary to the major competitors' slowdown in export growth, the country's sea food trade grew by double digit in quantum as well as value.

The fisheries sector despite being a heavy export earner (US\$ 5.51 billion) is facing numerous problems on account of economic, technological and institutional limitations, trade restrictions and lack of marketing network. India has to face severe competition from different countries such as Thailand, China and South East Asian countries for sustaining market share through product diversification. The seafood industry in many countries is undergoing a rapid transformation to process more ready-to-cook and ready-to-eat food in convenient packs. Indian seafood industry, by and large, still remains a supplier of raw materials to the pre-processors in foreign countries and 90 per cent of it goes in bulk packs, which is the prime reason for lower unit value realization.

The situation is not rosy with European Union countries with changing quality standards, cases of rejection and alerts and the recent European Catch Community Certificates. There are problems related to non-availability of raw materials and low capacity utilization of processing plants in India. The high cost on compliance for meeting the quality standards of EU countries not backed up with sufficient increase in export is another impediment faced by the exporters.

The consumption behaviour has been found skewed towards protein food with increased fish consumption on account of being healthier and cheaper amongst animal protein substitutes. The consumption studies have indicated the existence of huge demand for high- value fish even at a higher price. The poor supply of fish to the domestic fish market will lead to a situation wherein the domestic consumers will be devoid of fish in the market at affordable prices. The domestic fish food security is an important issue considering the fact that the export prices are lower than the domestic prices of fish coupled with umpteen trade restrictions and measures. The study has identified significant deleterious effect of fish demand - supply mismatch in the domestic market. The study has advocated government interventions in regulating fish exports to ensure domestic fish food security and substituting exports with domestic marketing. It is important to ensure the availability and affordability of high-value fishes whose consumption could be augmented by creating awareness in the country. The different stakeholders (fishers, traders, consumers, exporters and policymakers) need to be made aware about the market and price of fishes for evolving efficient marketing systems and supporting 
infrastructure (ice, cold storage, etc.) that would lead to better quality and prices. The development of a real time fish market grid to act as a decision support system would ensure fish market and price information dissemination about availability, accessibility and affordability of fish. However, with the current innumerable hassles in export of fish coupled with inefficient domestic marketing system, it is important to integrate domestic and international markets to ensure sustainability of fisheries trade. In view of huge forex reserves, competitive advantage over few exporting fish species, increasing purchasing power of the domestic consumers, changing consumer preferences and willingness to pay for the preferred ones, a concerted effort to regulate the export is highly recommended so that the fish will be available in the domestic market at affordable prices round the year, thereby ensuring fish food security for the domestic consumers.

\section{Acknowledgements}

The authors express their gratitude to Director, CMFRI, for funding the institutional projects which paved way for publishing the paper. The authors are also grateful to the learned referee for suggesting improvements in the paper.

\section{References}

CMFRI ( Central Marine Fisheries Research Institute) (2014) Annual Report 2013-14. Cochin. 272p.

CMFRI (Central Marine Fisheries Research Institute) (2015) Annual Report 2014-15. Cochin. 279 p.

Delgado, Christopher L., Wada, Nicholas, Rosegrant, Mark W., Meijer, Siet and Ahmed, Mahfuzuddin (2003) Outlook to Fish for 2020: Supply and Demand in Changing Global Markets. International Food Policy Research Institute, Washington, DC.

DFID (Department for International Development) (2003) Changing Food Utilization and its Impact on Poverty in Kerala. A project funded under DFID's Fisheries Post Harvest Research Programme.

FAO (Food and Agriculture Organization) (2006) The State of Food Security in the World. Rome.

FAO (Food and Agriculture Organization) (2005) National Aquaculture Sector Overview: India. Rome, updated 1 January 2005.
Garrett, H.E. and Woodworth, R.S. (1969) Statistics in Psychology and Education. Vakils, Feffer and Simons Pvt. Ltd., Bombay. 329 p.

Ghosal, Sutanuka (2011) Domestic fish prices jump on soaring demand in tier-II and tier-III cities. The Economic Times, August 1 : A3-A4.

Hazell, Peter, B.R., Mauricio, J. and Williamson, A. (1987) How Has Instability in World Markets Affected Agricultural Export Producers in Developing Countries? Policy Research Working Paper No. 263, World Bank.

Hazell, Peter B.R. (1982) Instability in Indian Foodgrain Production. Research Report 30. International Food Policy Research Institute, Washington, DC, USA. pp.II57.

Joseph, Sandu and Salim, Shyam S. (2012) Indian seafood trade: Implications, issues and policy imperatives. Seafood Export Journal, 42 (11): 36-42.

Krishnan, M. and Birthal, Pratap S. (2002) WTO and seafood exports: Performance, policy and potential. Indian Journal of Agricultural Marketing, Conference No. : 103-112.

Lusk, L. and Hudson, D. (2004) Willingness-to-pay estimates and their relevance to agribusiness decision making. Review of Agriculture Economics, 26: 152-169.

Maynard, L. and Franklin, S. (2003) Functional foods as a value-added strategy: The commercial potential of "cancer-fighting" dairy products. Review of Agriculture Economics, 25: 316-331.

Mohamed, K.S., Zacharia, P.U., Maheswarudu, G., Sathianandan, T.V., Abdussamad, E.M., Ganga, U., Pillai, S. Lakshmi, Sobhana, K.S., Nair, Rekha J., Jose, Josileen, Chakraborty, Rekha D., Kizhakudan, Shoba Joe and Najmudeen, T.M. (2014) Minimum Legal Size (MLS) of Capture to Avoid Growth Overfishing of Commercially Exploited Fish and Shellfish Species of Kerala. Marine Fisheries Information Service; Technical and Extension Series (220): 3-7.

Salim, Shyam S. (2012) Consumer's willingness to pay more for shrimps in Suburban Mumbai. Agricultural Economics Research Review, 25(2): 347-350.

Salim, Shyam S. (2013) Demand and supply paradigms for fish food security in India. Seafood Export Journal, 43(5): 34-40.

Salim, Shyam S. and Geetha, R. (2011) Stakeholders perception of Indo-ASEAN Free Trade Agreement on Indian Fisheries Sector. Journal of Indian Fisheries Association, 38: 1-9. 
Salim, Shyam S. and Narayanakumar, R. (2012) World Trade Agreement and Indian Fisheries Paradigms : A Policy Outlook Manual. Central Marine Fisheries Research Institute, Kochi. 484p.

Salim, Shyam S., Sekhar, C., Uma, K. and Rajesh, S.R. (2004) Indian fisheries in the context of globalisation. Indian Journal of Agricultural Economics, 59: 448-464.

Salim, Shyam S., Sathiadhas, R., Sathianandan, T.V., Geetha, R., Aswathy, N. and Vipinkumar, V.P. (2010) Marine fisheries resources: exploitation, management and regulations in India. Seafood Export Journal, 40(2): 25-34.

Salim, Shyam S., Rahman, Ramees M. and Antony, Bindu (2015) Sardine economy of Kerala: Paradigms and Perspectives. International Journal of Fisheries and Aquatic Studies, 2(6): 351-356.

Sathianandan, T.V., Jayasankar, J., Kuriakose, Somy, Mini, K.G. and Mathew, Wilson T. (2011) Indian marine fishery resources: Optimistic present, challenging future. Indian Journal of Fisheries, 58 (4): 1-15.

Unnithan, G.R., Kesavan Nair, A.K., Krishan Iyer, H. and Annamalai, V. (1998) Capacity utilization in the fish processing plants in Kerala. Fishery Technology, 35(2): 120-126.

Vivekanandan, E. (2011) Marine Fisheries Policy Brief-3; Climate Change and Indian Marine Fisheries. CMFRI Special Publication, 105. 97pp. 